\title{
Two new Orchidantha species (Lowiaceae) from Borneo
}

\author{
A.D. Poulsen ${ }^{1}$, J. Leong-Škorničková
}

Key words

Kubah National Park

Kuching

Malaysia

Matang

Mulu National Park

Orchidantha borneensis

Orchidantha holttumii

Sarawak

vulnerable

Zingiberales

\begin{abstract}
Two new Orchidantha species discovered in Sarawak, O. micrantha and O. megalantha, are described and illustrated. They may well represent the species with the smallest and the largest flowers currently known in the genus and certainly from Borneo. With its small flowers, O. micrantha is similar to O. borneensis to which it is compared. The large-flowered O. megalantha is compared to the morphologically closest species, O. holttumii, from nearby Brunei. The conservation status of both new species is assessed and a key is provided to all Bornean species.
\end{abstract}

Published on 26 September 2017

\section{INTRODUCTION}

Lowiaceae (Zingiberales), with a single genus Orchidantha N.E.Br., is a small family of about 21 species restricted to Asia. A more detailed general introduction to Lowiaceae was given in Trần \& Leong-Škorničková 2010. Recent work on Lowiaceae has uncovered several new taxa from continental Asia (Trần \& Leong-Škorničková 2010, Leong-Škorničková 2014, LeongŠkorničková et al. 2014, Zou et al. 2017) as well as one new species from Borneo (Syauqina et al. 2016). Eight species (and one variety) of the family Lowiaceae are found north of the Isthmus of Kra throughout the Indochinese floristic region and into southernmost China. Five different species occur on the Malay Peninsula and eight species are currently known to be endemic in Borneo.

Orchidantha borneensis N.E.Br., the type species of the genus, was the very first Orchidantha described (Brown 1886). The Compagnie Continentale d'Horticulture, Ghent, Belgium, introduced a live plant from Borneo to Europe without precise information of the locality of origin. The type specimen made from this cultivated plant, however, is well-preserved and the description is sufficiently detailed to establish that $O$. borneensis is a small species with light-coloured free and spreading sepals and a dark purple labellum and petals. Unfortunately, Larsen (1998) confused the understanding of the morphology of $O$. borneensis when he included a photograph by Josef Bogner. This photograph is of a cultivated plant, originally collected in 1994 at Matang, Sarawak, Borneo, flowering at Munich Botanical Garden in 1997 (acc. no. 94/1211). We studied pressed herbarium material of this plant (Bogner 2146, AAU (including four additional photographs), M). Due to the larger size of the flowers with white petals and a labellum with pale yellow apex, we have to conclude that this material does not match the type and original description of $O$. borneensis. Instead, Bogner's collection is very similar, if not conspecific, with the recently described O. ranchanensis Syauqina \& Meekiong, also from Sarawak.

1 Royal Botanic Garden Edinburgh, 20A Inverleith Row, Edinburgh EH3 5LR, Scotland; corresponding author e-mail: axel@dalbergpoulsen.com.

2 The Herbarium, Singapore Botanic Gardens, National Parks Board, 1 Cluny Road, Singapore 259569; e-mail: jana_skornickova@nparks.gov.sg.
New collections from Matang at the eastern side of Kubah NP (where Bogner collected 94/1211 between the national park headquarters and the Red Bridge, Bogner pers. comm.), and elsewhere in Sarawak are needed to completely understand the morphological variation and distribution of $O$. ranchanensis as well as establish the likely origin of $O$. borneensis.

Seven species of Orchidantha were subsequently described from Borneo: Larsen (1993), Nagamasu \& Sakai (1999), Pedersen (2001), Syauqina et al. (2016). Most of these are adequately described and illustrated, making identification of any new taxa uncomplicated and all are well localised. Two interesting Orchidantha species, first collected by ADP during fieldwork in Sarawak in 2003, are described and illustrated below as $O$. micrantha and O. megalantha, respectively. This brings the total number of Bornean species to ten with one species known from Brunei, four species each from Sabah and Sarawak and, as mentioned above, $\mathrm{O}$. borneensis, unlocalised. The descriptions of the vegetative characters are based on living plants and dry herbarium specimens, measurements of all flower parts were made from herbarium material preserved in spirit. The style of description follows recent works of Leong-Škorničková cited above, with general plant descriptive terminology following Beentje (2016).

\section{Orchidantha micrantha Škorničk. \& A.D.Poulsen, sp. nov.} - Fig. 1, 2

Similar to 0 . borneensis in the small habit and dark purple petals and labellum but differs in the overlapping lateral sepals supporting the labellum from below while the dorsal sepal arches above it (resulting in claw-like appearance of the flower vs sepals spreading), petals with irregularly serrate margin at apex (vs \pm entire) and the curved labellum with prominently undulate margin (vs labellum more or less flat without undulate margin). - Type: A.D. Poulsen, H.B. Mathisen, Vilma B. \& Jinaidi L. 2943 (holo SAR; iso E, SING), Malaysia, Sarawak, trail between Kubah National Park and Matang Wildlife Centre, $\mathrm{N} 1^{\circ} 36^{\prime} 46.14^{\prime \prime} \mathrm{E} 110^{\circ} 10^{\prime} 6.7^{\prime \prime}, 50$ m elevation, 19 Feb. 2014, flowering.

Etymology. The epithet refers to the small flowers relative to other species of the genus.

Clump-forming herb, up to $0.8 \mathrm{~m}$ tall, 7-14 leaves per shoot; juvenile plants as well as adult plants with distinctly petiolate 

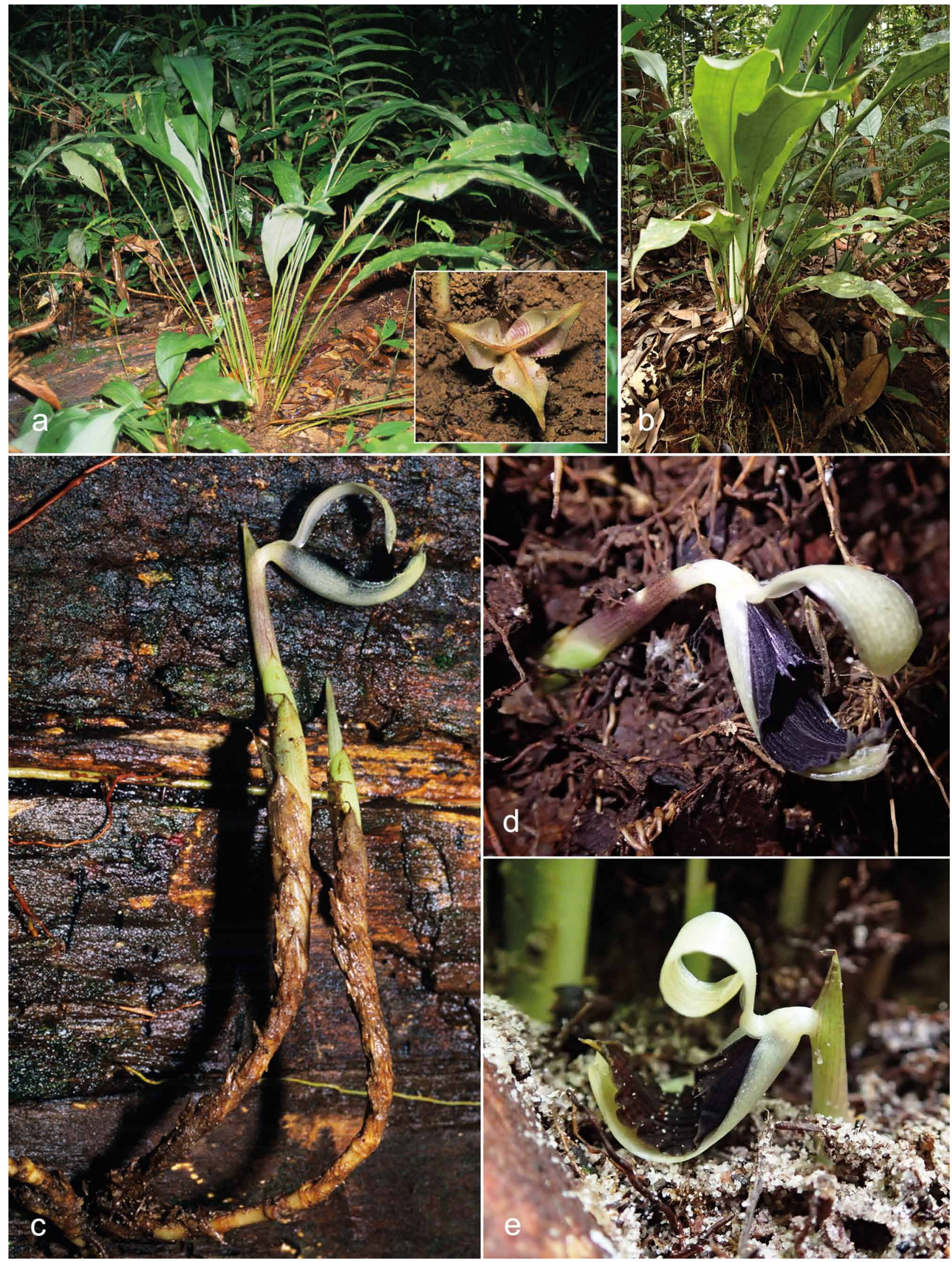

Fig. 1 Orchidantha micrantha Škorničk. \& A.D.Poulsen. a. Habit (inset: opened empty capsule); b. habit; c. inflorescence; d-e. details of flower (a, c: Poulsen et al. 2029; b, d-e: Poulsen et al. 2943). — Photos: Axel Dalberg Poulsen. 


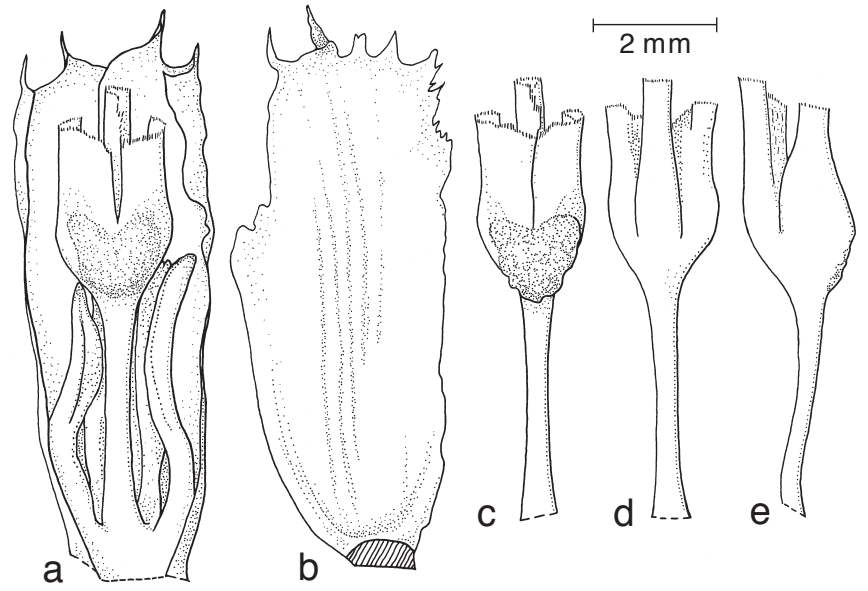

Fig. 2 Orchidantha micrantha Škorničk. \& A.D.Poulsen. a. Petals, stamens and style with stigma (ventral view); b. petal; c-e. detail of stigma in ventral, dorsal and lateral view (all: Poulsen et al. 2943, pickled material). — Drawing by Axel Dalberg Poulsen.

leaves; leaves to c. $1.2 \mathrm{~m}$ long, petiole $20-65 \mathrm{~cm}$, lamina unequal, narrowly elliptic, $23-55 \times 7-11 \mathrm{~cm}$, base asymmetrical, obtuse to attenuate, apex attenuate. Inflorescence on a slender, branched, pale to cream-coloured, burrowing stem with prominent bracts and/or their scars; prophyll triangular, two-keeled, c. $8 \mathrm{~mm}$ long; second bract c. $16 \mathrm{~mm}$ long, shortly sharply cuspidate; third bract c. $22 \mathrm{~mm}$ long, shortly sharply cuspidate; floral bract appearing above the soil or with the proximal part subterranean, pale green, sometimes tinged \pm purple towards apex, $35 \mathrm{~mm}$ long. Flowers emitting a pungent smell; pedicel c. $7 \mathrm{~mm}$ long; ovary extension c. $27 \mathrm{~mm}$ long, white to pale greenish; sepals greenish white, narrowly elliptic, shortly sharply cuspidate at apex, glabrous, entire; dorsal sepal c. $23 \mathrm{~mm}$ long, c. $7 \mathrm{~mm}$ wide; lateral sepals overlapping, often crossing and supporting the labellum, c. $25 \mathrm{~mm}$ long, 6-7 mm wide; lateral petals overlapping at base covering stamens and style, dark purple, elliptic, $8-8.5 \mathrm{~mm}$ long, c. $3 \mathrm{~mm}$ wide, outer margin undulate at the distal half, irregularly serrate at apex with a prominent mucro to $1 \mathrm{~mm}$ long; labellum ovate to elliptic with raised midrib (1-1.5 $\mathrm{mm}$ wide), c. $23 \mathrm{~mm}$ long (incl. the $1 \mathrm{~mm}$ long acuminate tip), c. $10 \mathrm{~mm}$ wide, dark purple throughout, with the very tip fading to a dirty orange in 2 nd day flowers; sides reticulate with vertical lines much more pronounced, margin prominently undulate distally. Stamens c. $5 \mathrm{~mm}$ long; filaments 1.5-2 mm long; anther thecae introrse, 3-3.5 mm long, longitudinally dehiscent throughout their length. Style c. $3.5 \mathrm{~mm}$ long; stigma $3.5 \mathrm{~mm}$ long, deeply 3-lobed, conduplicate, margin irregularly denticulate, median lobe c. $2 \mathrm{~mm}$ long; lateral lobes c. $1.5 \mathrm{~mm}$ long; viscidium bluntly heart-shaped and extending from the base to about $1 / 3$ of the lateral lobe (pronounced in side view); side of the heart-shape 1.5-2 $\mathrm{mm}$ long. Fruit a 3-locular, loculicidal capsule, ovoid, narrowing to a beak at apex, bluntly trigonous, c. $40 \mathrm{~mm}$ long (incl. the 5-8 $\mathrm{mm}$ long beak), c. $15 \mathrm{~mm}$ diam (young fruit $27 \times 10 \mathrm{~mm}$ ), dark violet to almost black externally, straw-coloured with pink-purple shades internally, dehiscing longitudinally; seeds (from not fully mature fruit) c. $6 \times 4 \mathrm{~mm}$, glabrous, ampulliform with a seed coat swelling at base forming a neck that bears $2-4$ aril threads, aril threads up to $8-11 \mathrm{~mm}$ long, curled, glabrous.

Distribution - So far known only from two locations on the western side of Kubah National Park near Kuching, distanced within one kilometre from each other.

Habitat \& Ecology - Kerangas forest, flat area near river (Poulsen et al. 2029) and low dipterocarp forest, on sandy soil (Poulsen et al. 2943). Flowering recorded in February and July.

Other specimen examined. MALAYSIA, Sarawak, Sungai Rayu, N1³7' E110 $10^{\prime}, 50$ m elevation, 2 July 2003, flowering and fruiting, A.D. Poulsen, Effendy Supot, Jais \& Jugah 2029 (AAU, E, L, SAR, Sarawak Biodiversity Centre).

Conservation status - Orchidantha micrantha is reported from two populations each of several individuals a few hundred metres apart at the same general habitat within a protected area with no perceived threats. As the number of mature individuals is < 1000, it may be considered 'Vulnerable' (VU) D1 (IUCN Standards and Petitions Subcommittee 2017).

Notes - 1. In Borneo, this species is most similar to O. borneensis due to its small habit, and similarity in size and colouring of the flower although the differences in flower structure as outlined in the diagnosis makes the two species unmistakeable. Further differences between the two species, based on

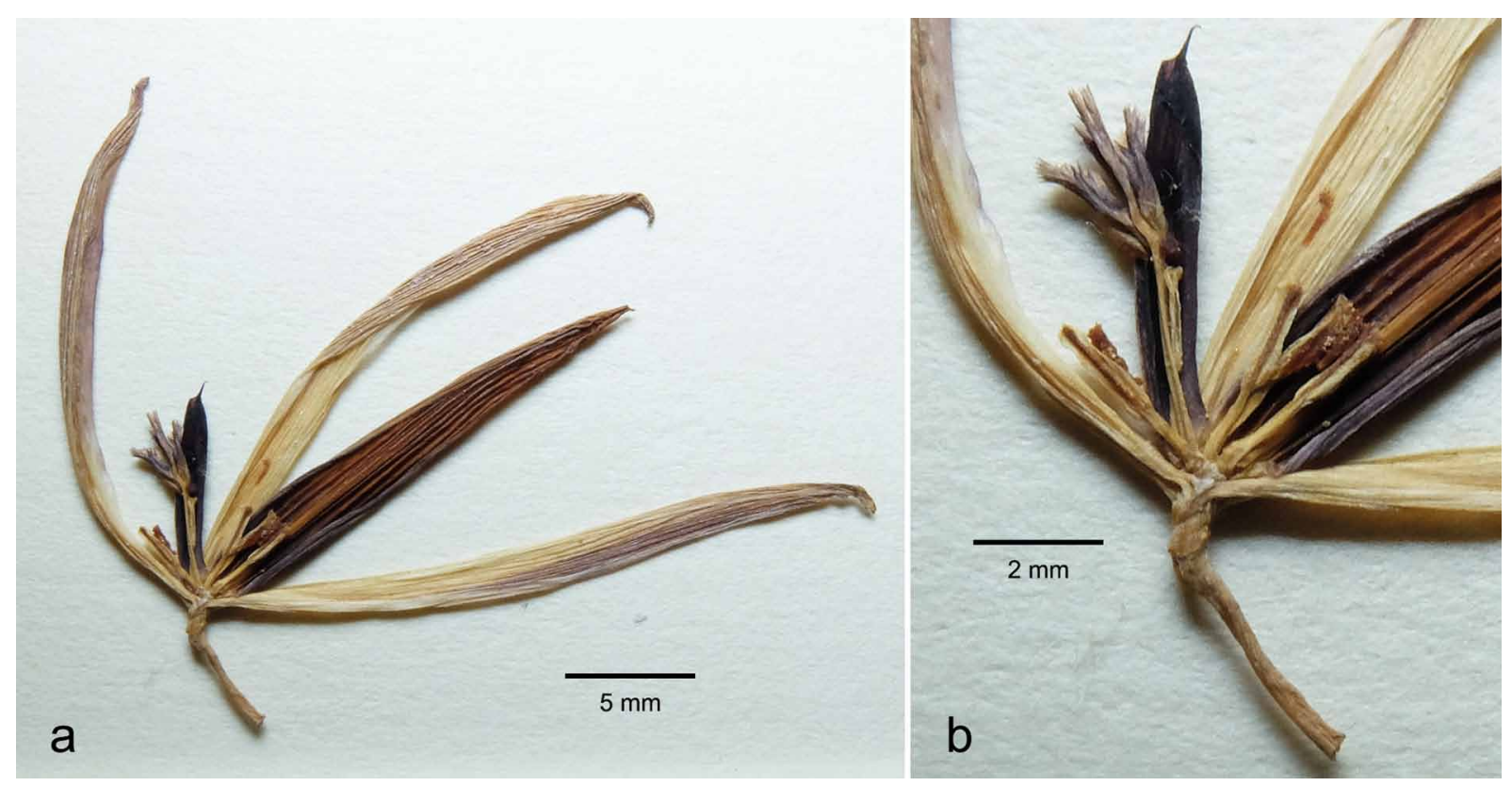

Fig. 3 Orchidantha borneensis N.E.Br. a. Flower; b. detail of stigma, stamens and petal (all of the holotype at K [K000292159] reproduced with permission of the Director and Board of Trustees, Royal Botanic Gardens, Kew). — Photos: Jana Leong-Škorničková. 

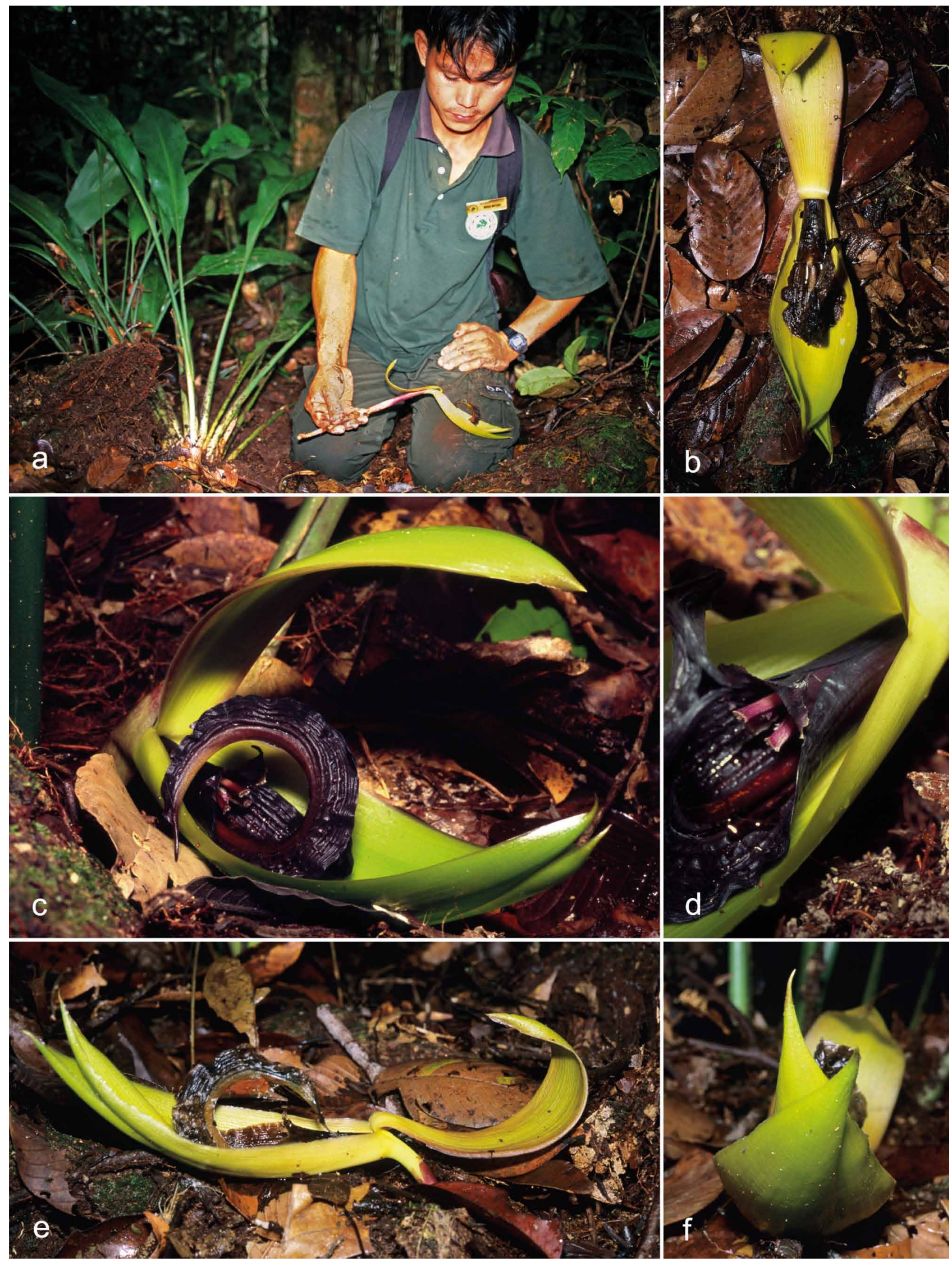

Fig. 4 Orchidantha megalantha Škorničk. \& A.D.Poulsen. a. Habit and Biogo Mutang holding a flower at the type locality; b. old flower (front view); c. fresh flower (oblique view); d. detail of base of the labellum, petals and stigma; e. old flower (side view; note the reflexed dorsal sepal); f. detail of lateral sepals with crossed apices supporting the labellum (all: Poulsen et al. 2073). — Photos: Axel Dalberg Poulsen. 
examination of the type specimen of $O$. borneensis which has two well-preserved flowers (Fig. 3) can be outlined as follows: Orchidantha micrantha has petals where the margin at apex is irregularly serrate, an ovate to elliptic labellum c. $23 \times 10 \mathrm{~mm}$ with a prominent midrib throughout the entire length, and the margin to the stigma is irregularly denticulate whereas $O$. borneensis in comparison has petals with an entire margin, a linear c. $21 \times 3.5 \mathrm{~mm}$ labellum where the midrib is only prominent in the lower half, and the stigma margin laciniate. The recently described O. ranchanensis from Sarawak also has spreading sepals and is therefore easy to distinguish from O. micrantha.

2. In continental Asia, the morphologically most similar species would be $O$. stercorea H.Đ. Trần \& Škorničk. (colour figure in Trần \& Leong-Škorničková 2010) and O. laotica K.Larsen (colour figure in Zou et al. 2017). Both species are small and have flowers with a dark labellum in a claw-like arrangement of pale-coloured sepals. Neither of these species has an undulate labellum margin. In addition, O. laotica has lamellate yellow stripes at the base of the labellum, while the flowers of $O$. stercorea are larger than those of O. micrantha.

\section{Orchidantha megalantha Škorničk. \& A.D.Poulsen, sp. nov.} - Fig. 4, 5

Similar to O. holttumii in overall habit, the petiolate leaves, and the claw-like arrangement of the petals, but differing in the larger flowers with slightly unequal sepals (vs equal), dorsal sepal $14-15 \times 4-4.1 \mathrm{~cm}$, lateral sepals $15-16 \times 3.7-3.9 \mathrm{~cm}$ (vs c. $9 \times 2 \mathrm{~cm}$ ), labellum $12.5-13.5 \times$ c. $4 \mathrm{~cm}$ (vs $7 \times$ $2 \mathrm{~cm}$ ) and purple stigma (vs white). - Type: A.D. Poulsen \& Biogo Mutang 2073 (holo SAR; iso AAU, Sarawak Biodiversity Centre, SING), Malaysia, Sarawak, Mulu NP, shortcut trail between the Penan village and Gunung Mulu, $\mathrm{N} 4^{\circ} 02^{\prime} \mathrm{E} 114^{\circ} 49^{\prime}, 30$ m elevation, 17 July 2003, flowering.

Etymology. The epithet refers to the large flowers relative to other species of the genus.

Robust clump-forming herb, up to $1 \mathrm{~m}$ tall, c. 14-15 leaves per shoot; juvenile plants as well as adult plants with distinctly petiolate leaves; leaves to $1.3 \mathrm{~m}$ long (including petiole), petiole up to $55 \mathrm{~cm}$; lamina unequal, elliptic, to $75 \times 15.5 \mathrm{~cm}$, base asymmetrical, attenuate, apex narrowly attenuate. Inflorescence on a slender, branched, pale to cream-coloured, burrowing stem with prominent bracts and/or their scars; prophyll triangular, twokeeled, 22-23 mm long, 13-14 mm wide at base; second bract 30-42 mm long, c. $15 \mathrm{~mm}$ wide at base, shortly cuspidate; third bract 45-60 mm long, c. $20 \mathrm{~mm}$ wide at base, shortly cuspidate;

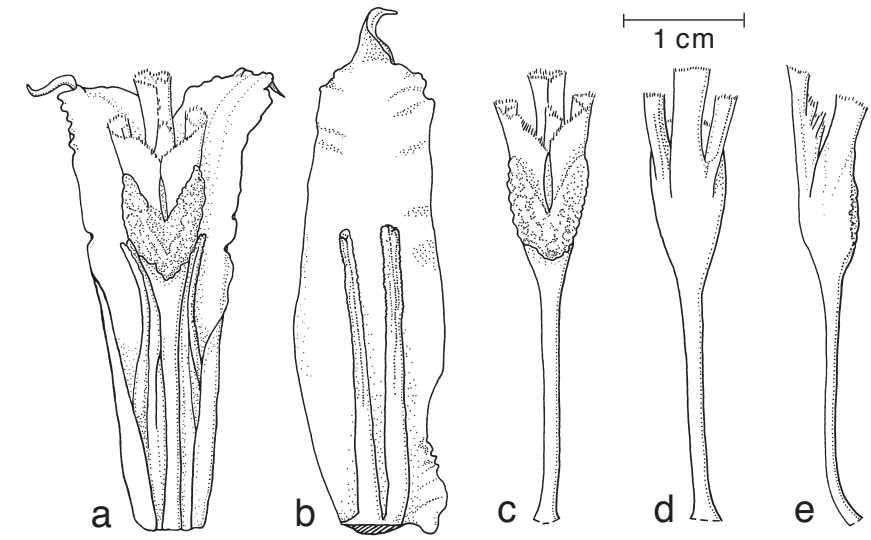

Fig. 5 Orchidantha megalantha Škorničk. \& A.D.Poulsen. a. Petals, stamens and style with stigma (ventral view); b. petal with two stamens attached; c-e. detail of stigma in ventral, dorsal and lateral view (all: Poulsen et al. 2073, pickled material). — Drawing by Axel Dalberg Poulsen.

floral bract burrowed in the soil at base, apex appearing above the soil, green with a rich rusty-red tinge apically when exposed above ground, 90-130 mm long, c. $32 \mathrm{~mm}$ wide. Flower smell not recorded; pedice/ c. $30 \mathrm{~mm}$ long; ovary extension c. $100 \mathrm{~mm}$ long, cream-white at base to green-yellow apically; sepals yellow-green (dorsal sepal with a slight rusty-red tinge particularly towards the sides), narrowly elliptic, cuspidate, glabrous, entire; dorsal sepal 140-150 mm long, 40-41 mm wide (cusp c. $3 \mathrm{~mm}$ ); lateral sepals overlapping, often crossing and supporting the labellum, 150-160 mm long, 37-39 mm wide, cuspidate at apices (cusp c. 5-6 mm); lateral petals overlapping at base covering stamens and style, dark purple, irregularly elliptic, cuspidate (cusp 3-4 mm, recurved), 40-42 mm long, 11-12 mm wide, outer margin undulate at the distal half; labellum elliptic with strongly raised midrib (c. $4 \mathrm{~mm}$ wide), $125-135 \mathrm{~mm}$ long (including a 5-10 $\mathrm{mm}$ long acuminate tip), c. $40 \mathrm{~mm}$ wide, dark purple throughout but slightly fading towards apex, sides strongly reticulate with vertical lines more pronounced, sides and margins of labellum undulate and involute distally. Stamens c. $25 \mathrm{~mm}$ long; filaments 7-8 $\mathrm{mm}$ long, $2 \mathrm{~mm}$ broad, cream-white with slight purple tinge; anther thecae introrse, 14-15 mm long, longitudinally dehiscent throughout the length. Style creamwhite, c. $21 \mathrm{~mm}$ long; stigma c. $17 \mathrm{~mm}$ long, deeply 3-lobed, dorsal surface and stigma lobes tinged purple, conduplicate,
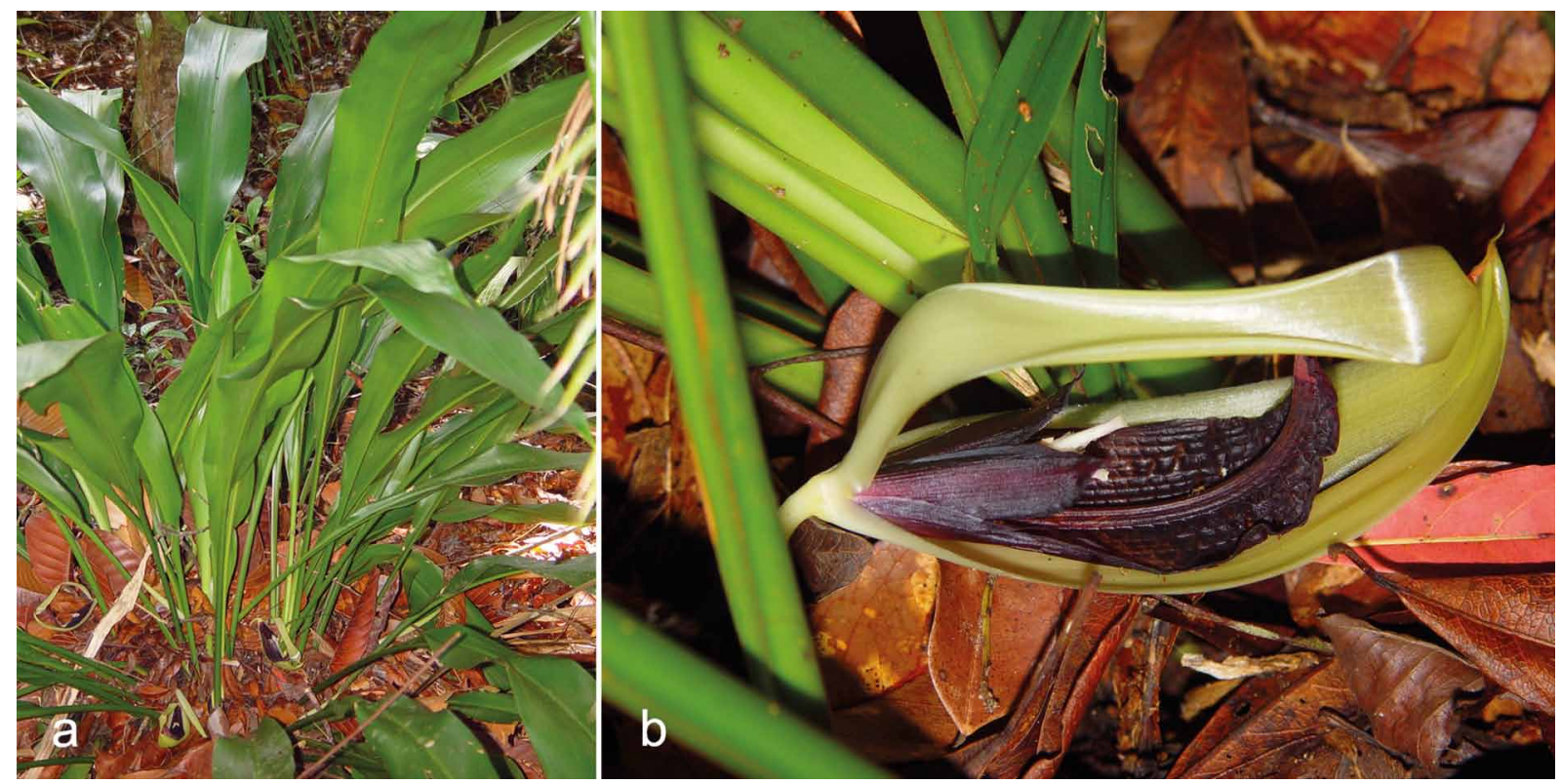

Fig. 6 Orchidantha holttumii K.Larsen. a. Habit; b. flower (ex-situ collection at Sungai Liang, Brunei). — Photos: Muhd Ariffin Abdullah Kalat (BRUN). 
margin membranous, minutely laciniate, median lobe c. $11 \mathrm{~mm}$ long; lateral lobes c. $10 \mathrm{~mm}$ long; viscidium V-shaped and extending from the base to about half of the lateral lobe (pronounced in side view); side of the V-shape c. $9 \mathrm{~mm}$ long.

Distribution - So far known only from the type locality.

Habitat \& Ecology - Growing on a sandy hill c. $300 \mathrm{~m}$ from a limestone cliff. Flowering observed in the field in April and July.

Conservation status - Orchidantha megalantha is reported from one population on a sandy shallow hill with several individuals within a national park area with no perceived threats. As the number of mature individuals is $<1000$, it may be considered 'Vulnerable' (VU) D1 (IUCN Standards and Petitions Subcommittee 2017).

Note - Orchidantha megalantha resembles 0 . holttumii K.Larsen (Fig. 6) by the height not exceeding $1.5 \mathrm{~m}$ and the presence of petiolate leaves in both young and adult individuals. The shape of the flower is also similar; the two lateral sepals overlapping below the labellum and the dorsal sepal arching over it, resulting in claw-like appearance of the flower. The flower of $O$. megalantha is, however, twice as big as that of $O$. holttumii, the sepals are bright yellow-green and stigma is purple (compared to pale greenish sepals and white stigma in O. holttumii). So far, all species of Orchidantha are known to be very restricted in their distribution (Sakai \& Inoue 1999). The difference in the size and colouration of the flower is likely an adaptation to a specific pollinator, most likely a dung beetle, as previously reported for other species of Bornean Orchidantha (Sakai \& Inoue 1999, Pedersen 2001).

\section{KEY TO THE BORNEAN SPECIES OF ORCHIDANTHA}

1. Lateral sepals overlapping and supporting the labellum . 2

1. Lateral sepals spreading, not supporting the labellum. . 7

2. Leaves of adult plants clearly petiolate . . . . . . 3

2. Leaves of adult plants without petiole, base attenuate . . 6

3. Labellum broadly elliptic, shallowly boat-shaped, dark purple at base, gradually changing to warm yellow towards apex . . . . . . . . . . . . . . . . . . . . quadricolor

3. Labellum more or less involute with prominently raised midrib and more or less undulate margins, plain dark purple. . . 4

4. Flowers small: sepals and labellum not exceeding $2.5 \mathrm{~cm}$ . . . . . . . . . . . . . . . . . . . O. micrantha

4. Flowers large: sepals more than $9-16 \mathrm{~cm}$ long and labellum $7-14 \mathrm{~cm}$ long $\ldots \ldots \ldots \ldots \ldots \ldots \ldots \ldots \ldots \ldots$

5. Sepals c. $9 \mathrm{~cm}$ long. Labellum c. $7 \mathrm{~cm}$ long .. O. holttumii

5. Sepals $14-16 \mathrm{~cm}$ long. Labellum $12.5-13.5 \mathrm{~cm}$ long . . . . . . . . . . . . . . . . . . . O. megalantha

6. Sepals $73-100 \times 11-12 \mathrm{~mm}$. Petals whitish with purple tips . . . . . . . . . . . . . . . sabahensis

6. Sepals $57-70 \times 11-14(-18) \mathrm{mm}$. Petals plain dark purple $\ldots \ldots \ldots \ldots \ldots \ldots \ldots \ldots$. . suratii

7. Labellum purple with yellow or whitish apex, sometimes also with whitish midrib (Sarawak) . . . . . . . . . . . 8

7. Labellum blackish violet or dark purple throughout . . . . 9

8. Lamina $70-120 \times 11-15 \mathrm{~cm}$. Labellum purple with whitish apex..................... inouei

8. Lamina $22-40 \times 6-10 \mathrm{~cm}$. Labellum purple with yellow apex.................... ranchanensis

9. Robust plant to $1.5 \mathrm{~m}$ tall. Labellum $97-117 \times 40-45 \mathrm{~mm}$, including to $7 \mathrm{~mm}$ long acumen ........ O. grandiflora

9. Small plant c. $0.3 \mathrm{~m}$ tall. Labellum c. $21 \times 3.5 \mathrm{~mm}$
Acknowledgements Sarawak Biodiversity Centre (SBC) provided permits for research on Zingiberales in Sarawak for the first author in 2003; the Forest Department in Sarawak gave permission to conduct the research in 2014. His fieldwork was kindly supported by HRH Frederik, Crown Prince of Denmark. The research of the second author was supported by the National Parks Board, Singapore and by the Czech Science Foundation, GAČR (Grant No. P506/14/13541S). We should also like to thank the keepers of the herbaria of AAU, E, K, KEP, M, P, SAN, SAR and SING for letting us examine their collections and sending material on loan, staff at SBC and Forestry Research Centre, Mulu NP and Kubah NP in Sarawak for logistic and other help, and Muhd Ariffin Abdullah Kalat (BRUN) for letting us use his photographs of $O$. holttumii. At Munich Botanical Garden, we are grateful to its director, Susanne S. Renner for inviting the first author on a research visit, Josef Bogner for providing locality information of his collection and useful discussions, Till Hägele for checking accessions in the live collection database and Hajo Esser for providing digital images of herbarium specimens. Fig. 3 is reproduced with permission of the Director and Board of Trustees, Royal Botanic Gardens, Kew.

\section{REFERENCES}

Beentje H. 2016. The Kew Plant Glossary, an illustrated dictionary of plant terms (revised edition). Royal Botanic Gardens, Kew, Kew Publishing.

Brown NE. 1886. Orchidantha borneensis, a new genus of Scitamineae. Gardeners' Chronicle n.s. 26: 519.

IUCN Standards and Petitions Subcommittee. 2017. Guidelines for using IUCN Red List Categories and Criteria. Version 13. Prepared by the Standards and Petitions Subcommittee. Downloadable from http://www. iucnredlist.org/documents/RedListGuidelines.pdf.

Larsen K. 1993. A new species of Orchidantha (Lowiaceae) from Borneo. Nordic Journal of Botany 13: 285-288.

Larsen K. 1998. Lowiaceae. In: Kubitzki K (ed), The families and genera of vascular plants, vol. 4: 275-277. Springer-Verlag, Berlin. doi: https://doi. org/10.1007/978-3-662-03531-3_30.

Leong-Škorničková J. 2014. Orchidantha lengguanii (Lowiaceae), a new species from Peninsular Malaysia, and typification of $O$. maxillarioides. Gardens' Bulletin Singapore 66 (1): 15-25.

Leong-Škorničková J, Nguyễn QB, Šída O. 2014. Orchidantha virosa Škorničk. \& Q.B.Nguyễn, sp. nov. (Lowiaceae), a new species endemic to northern Vietnam. Adansonia sér. 3, 36 (2): 237-243. doi: https://doi. org/10.5252/a2014n2a6.

Nagamasu H, Sakai S. 1999. Orchidantha inouei (Lowiaceae), a new species from Borneo. Nordic Journal of Botany 19: 149-152.

Pedersen LB. 2001. Four new species of Orchidantha (Lowiaceae) from Sabah. Nordic Journal of Botany 21: 121-128.

Sakai S, Inoue T. 1999. A new pollination system: dung-beetle pollination discovered in Orchidantha inouei (Lowiaceae, Zingiberales) in Sarawak, Malaysia. American Journal of Botany 86 (1): 56-61.

Syauqina MY, Meekiong K, Tawan CS, et al. 2016. Orchidantha ranchanensis, a new species of Lowiaceae from Sarawak, Malaysia. Folia malaysiana 17 (2): 35-42.

Trần HĐ, Leong-Škorničková J. 2010. Orchidantha stercorea sp. nov. (Lowiaceae) from Vietnam. Nordic Journal of Botany 28: 299-303. doi: https:// doi.org/10.1111/j.1756-1051.2009.00704.x.

Zou P, Xiao C-F, Luo S-X, et al. 2017. Orchidantha yunnanensis (Lowiaceae), a new species from China, and notes on the identity of Orchidantha laotica. Phytotaxa 302 (2): 181-187. 